\title{
Inclusive schools: Are teachers adequately prepared for inclusion?
}

ABSTRACT: Dikla Divon, Inclusive schools: Are teachers adequately prepared for inclusion? Interdisciplinary Contexts of Special Pedagogy, no. 30, Poznań 2020. Pp. 33-51. Adam Mickiewicz University Press. ISSN 2300-391X. e-ISSN 2658-283X. DOI: https:// doi.org/10.14746/ikps.2020.30.02

This article will discuss one of the main topics on the educational and social agendas in Israel. Integrating children and adults with special needs into schools and the community is a worldwide issue. Many researchers have tried to find and evaluate the most effective integration methods, to assist people with special needs and enable them high quality of life and equality. In this article, we will look at the process of integrating students with special needs and the transition that took place during the last few decades regarding the idea of "inclusion", which is now a top priority for the Ministry of Education's directors. Based on recent studies, we will examine whether school teaching staff and student teachers are ready to implement inclusive programs in schools as required. We will then propose ways to optimize the training of the educational staff, towards the implementation of the inclusive programs.

KEY WORDS: Education, Special Education, Integration, Inclusion, Inclusive Schools

\section{Introduction}

Integration and inclusion of children and adults with special needs in schools and the community are two issues on the educational and social agenda of many countries, including Israel. Many researchers are examining different ways of integration, to find the 
most effective way of integration for people with special needs both in facilitating the integration process and in the success of the integration, manifested in improving the quality of life and equality for those integrated. In this article, we will examine the process of integrating students with disabilities in Israel since the enactment of the "Special Education Act" in 1988 and up to the formulation of the "inclusion" concept, which is favored by the Ministry of Education and is still being implemented.

In this paper, we will review the following issues:

- When did the discourse on "inclusion" come to the forefront of educational priorities? Equally important, what was the founding event that initiated it?

- What is the added value of inclusion over integration?

- We will discuss the ability of teachers and student teachers to implement the school inclusion programs, according to the $11^{\text {th }}$ amendment of the Special Education Act.

- Based on a literature review, we will present a model for preparing student teachers to teach according to the 11th amendment of the aforementioned law.

\section{Integration in Israel - historical review}

The philosophical concept underlying the idea of integration is that a child with special needs has the same rights as a child without such needs; therefore, he has the basic right to study together with his peers within the same educational system.

Studies suggest that separating a child with special needs from his peers will inevitably result in future difficulties. Separating a child or an adult with special needs from the rest of society is a discriminatory action, designated to make the lives of "ordinary" people easier. ${ }^{1}$ Excluding the "weak" people, allegedly to protect them, indicates discrimination and not consideration.

רונן ח. 1997" .הכללתם של ילדים חריגים בחינוך הרגיל. סוגיות בחינוך מיוחד ובשיקום"..1 .29-21:(2)12 
Referral ofhildren with special needs to special education shifts the responsibility of care from the regular school, to the disabled individual and to the therapeutic staff. In doing so, it dismissed the regular educational system from responsibility and from the need to address the problems of children with special needs. Indeed, there are special children who need more teaching time and more time for learning; but in principle, disabled children do not need instruction that is fundamentally different from the instruction provided to their normally developing peers. According to this approach, special education teachers are educators with special skills and not educators of special children. ${ }^{2}$

The philosophical concept that considers the disabled individual as an integral part of society, led to two complementing models that aim to achieve de facto integration of the special individual in society: the behavioral model, which advocates the principle of normalization, and the humanistic-educational model.

\section{The behavioral model - the principle of normalization}

One of the social changes that derived from the struggles of human rights movements, is the integration model - based on the concept of normalization. This concept developed in the United States and has manifested itself in two areas: 1) Legislation aimed at equal rights, equal opportunities, and affirmative action that would enable "normal life" in the community. 2) Integration of students with special needs into the public education system, in order to prepare them for a normal life. ${ }^{3}$

רונן ח. 1997" .הכללתם של ילדים חריגים בחינוך הרגיל. סוגיות בחינוך מיוחד ובשיקום"..2 29-21:(2)12

רייטר, ש. 1999" .איכות חייו של הילד בעל הצרכים המיוחדים לאור הרחבת עקרון 3

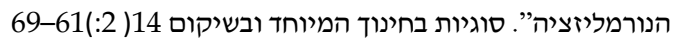


The behavioral concept has received much criticism for adhering to the medical model, according to which the abnormality must be "cured" and made "normal". The behavioral model dictated systematic ways of working and clear stages of diagnosis, defining the "disease", implementing an intervention program that determines the environmental conditions and subsequent treatment, and examining the results in light of the criterion of health or normality versus illness or abnormality. Although the behavioral method was found to be effective and was widely used in educational and rehabilitation institutions, it entailed omitting the uniqueness of the individual. The goal of normalization was achieved, perhaps, but the price was the disabled people's isolation and alienation, despite living within the community. No wonder adults with disabilities began to make claims and requests to live meaningful, interesting, and independent lives and to be able to make their own decisions. ${ }^{4}$

\section{The humanistic-educational model}

The humanistic-educational model, focusing on the disabled individual and his rights, was developed as an alternative to the behavioral model. This model maintains a holistic approach towards the individual and the social, therapeutic, educational, and rehabilitation services provided to him. According to this model, true integration is a two-way activity of the individual and society, rather than a one-way activity of preparing the disabled person to be like everyone else. True integration means cultivating the ability of the disabled person to live a meaningful life of dignity with the inclusion of the disability, and at the same time preparing society to accept people with disabilities and handicaps as ordinary people and adapt the services it provides to their needs. The keyword in this model is respect for the individual.

רייטר, ש. 1999" .איכות חייו של הילד בעל הצרכים המיוחדים לאור הרחבת עקרון 4

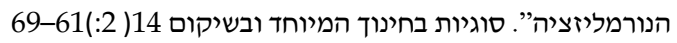




\section{From normalization to inclusion and integration}

According to the integration model, which is based on the behavioral model and the humanistic-educational model, people with disabilities should live in conditions as similar as possible to those of ordinary people in all areas of life: residence, work, study, leisure, etc. To this end, they should be granted the same civil rights given to other citizens. At the same time, in a gradual process, the understanding began to take root that the integration model was not sufficient and thus the idea of inclusion began to form. The idea of inclusion is a perceptual change in the concept of "normalization" underlying the integration model. The change is manifested in the transition from an attempt to "change" a person with special needs and "normalize" him, to a desire to "include" them as they are and adapt society to them. The inclusion model shifted its weight to the humanistic model with an increasing demand that society should adapt itself and accommodate those with special needs. The concept of inclusion stemmed from scholars from Scandinavia and the US, who believed that for de-facto equality, it is not enough to adapt people with special needs to society, but also vice versa. ${ }^{5}$ For that to happen, the public should be educated to accommodate people with special needs and should acknowledge that they are able to live in good conditions, no less than those of an average citizen. Without a profound social change of consciousness, all people with special needs will still be considered "different", will not receive basic human respect and dignity. Not because they are incapable, but because they do not meet the criteria set by the mainstream. The rights of people with disabilities should be enshrined in law, which will guarantee them equal rights.

The weak point of the principle of normalization lies in the interpretation of the term "normal". There was a general misconception that normal means good and disabled means not-good. This

רייטר, ש' לייזר, י' ואבישר, ג' (עורכים). (2007). שילובים: לומדים עם מוגבלויות במערכות 5 חינוך, חיפה : אחווה. 
perception defined how to address people with special needs; in educational settings, the staff believed that people with special needs should be "normalized" as much as possible. People with special needs would like to be accepted as they are. ${ }^{6}$

In recent years, the principle of normalization has been redefined. This new definition corresponds to the ethos of a heterogeneous and democratic society, and it focuses on society's readiness to integrate all individuals. In order to accommodate people with disabilities, a two-level, comprehensive accessibility is needed: (a) the physical level: the public space must be adapted and made accessible to the physical limitations of people with special needs; (b) the perceptual level: there is a need to change basic attitudes towards people with special needs, consider them as human beings and accept them as they are and not as disabled people who should be corrected. Following the critique on the concept of normalization among the professional community, there was a tendency to replace the term 'normalization'/'integration' with the terms 'inclusion' and 'participation'. The term 'inclusion' expresses the basic legal right of equality. The two main laws in Israel that address integration are the Special Education Law and the Equal Rights for Persons with Disabilities Law.7,8

The purpose of these laws was determined in the body of the law as follows:

Section 2 of the Special Education Law provides as follows:

2. The goals of special education services are -

(1) To promote and develop learning, competencies, and abilities of students with special needs and their physical, mental, emotional, social and behavioral functioning as well as to provide them with knowledge, life skills, and social skills;

רייטר, שי לייזר, " ואבישר, ג' (עורכים). (2007). שילובים : לומדים עם מוגבלויות במערכות חינוך, 6 חיפה: אחווה.

7 Special Education Law, 1988.

8 Special Education Law, 1988. 
(2) To ensure the right of students with special needs for equal and active participation in society, in all areas of life, and to provide an appropriate response to their special needs in a way that will enable them to live in maximal independence, privacy, and dignity, while realizing their abilities;

(3) To promote the integration of students with special needs in regular educational institutions. ${ }^{9}$

The Equal Rights for Persons with Disabilities Law:

(2) To protect the dignity of people with special needs and ensure their right for equal and active participation in society, in all areas of life, and to provide an appropriate response to their special needs in a way that will enable them to live in maximal independence, privacy, and dignity, while fully realizing their abilities. ${ }^{10}$

\section{Integration in Israel - historical review}

In 2002, the Israeli Special Education Law was extended and is now referred to as the Integration Law, which addresses the integration of children with special needs in regular education. Article 20B of the proposal states:

"An integrated student is entitled, as part of his studies at a regular educational institution, to supplemented teaching and learning as well as to special services..." (section $20 \mathrm{~b}$ ).

The amendment specifies the composition of the Integration Committee, whose role is to determine the eligibility of a student with special needs in a regular school and the need to tailor an educational program for each integrated student. The amendment clear-

9 Special Education Law, 1988.

${ }^{10}$ Equal Rights for Persons with Disabilities Law, 1998. 
ly states, for the first time, the necessity to integrate children with special needs into the regular education system, with the addition of special instruction and special services. In addition, the decision on eligibility for each child will be made at the school level according to the recommendation of the integration committee, in cooperation with the parents. That is, parental involvement and partnership are now enshrined in legislation and parents can appeal to the committee. The Special Education Law and its expansion in 2002 has a new chapter that defines educational integration as the desired outcome - giving preference to the regular educational system over special education; providing special education services and regular care within the regular framework; and extending parental participation in making decisions concerning their children, their participation in placement committees and disclosure of documents to the parents. The Ministry of Education has established three different frameworks for the integration of special education students: a special education school, a special education class in a regular school (an advancing class), and individual integration in a regular class and a regular school.

In recent years, there has been growing public interest in integrating children with disabilities into the regular education system. This interest is reflected in the increasing involvement of organizations and associations, in discussions in the Knesset (Israeli parliament) committees, in the legal-legislative field, in petitions submitted to the courts, and in the establishment of a public committee (chaired by former judge Dalia Dorner) to examine the policy regarding of students with special needs. This committee examined the implementation of the integration section of the law and recommended various improvements: parental involvement and letting them choose the suitable framework for their child; preferring a flexible budgeting method - "the budget follows the child"; individual decision on the child's placement, according to his level of functioning; training and professional development for the teacherassistants; training teachers from the regular education track; proper 
equipment of special education settings and locating them near regular schools.

A Brookdale Institute (2010) report revealed that graduates of the system who have been integrated into regular education, report a lack of social connections after school hours. The report indicated that the educational integration at schools does not enhance the social lives of students with special needs in the after-school hours, that is, integrated students have few after-school social experiences. Another finding was that all students in schools where children with disabilities were integrated did not receive adequate preparation. It was also found that the integrated students do not receive a life preparation program and do not have the skills needed to integrate into society. ${ }^{11}$

These findings indicate that "it takes two to tango". That is, the inclusion target (Objective 12) of the Ministry of Education, which has been implemented since 2012, requires that the regular schools should be adept at accommodating students with special needs. This step is critical, as are the integration and life-skills programs for students with special needs. Consequently, those students do not enjoy an optimal social life and do not take an active part in the community.

\section{Integration and quality of life}

The concept quality of life represents an ideology and a sociopolitical strategy that has been more prevalent in the last two decades. This means that it is not enough to strive for the integration of the individual in a more normative framework, but that he or she must be guaranteed quality of life. ${ }^{12}$ The term 'quality of life' pre-

מעקב :יסודיים ספר-בבתי מיוחדים צרכים עם ילדים שילוב. 2011 .מ ,מרום ;.א, ,מילשטיין ;.ד ,נאון 11 , משירון

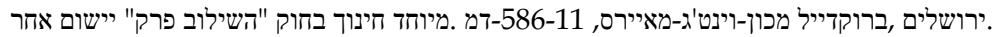

12 Schalock R.L. (2000), Three Decades of Quality of life. In Wehmeyer M., Patton J. (Edt), Mental Retardation in the 21st Century. pp. 335-356. PRO-ED, Inc.

רייטר, ש. 1999" .איכות חייו של הילד בעל הצרכים המיוחדים לאור הרחבת עקרון הנורמליזציה".

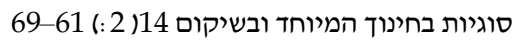


sents an alternative paradigm to the medical paradigm on which the special education system was based. The integration movement, which created an education reform, expanded the meaning of the term 'quality of life' and applied it to every student that is different from the norm in his surroundings, in terms of origin, socio-economic status, etc. According to this paradigm, the educational framework should tailor an individual program for each child and adolescent with disabilities, after finding out about the student's needs, preferences, and abilities. It will take into consideration his opinion and allow him to make choices and decisions. The program is supposed to take into account various aspects - social ones, independence, physical comfort, personal development, and psychological well-being. Contrary to the integration movement, which was based on the medical model, the inclusion movement, which is based on the social model, contends that disability is not a feature of the individual but a state of interaction between the individual and his environment and the assistance provided to him. That is, the manifestation of disability is a product of social definition because society decides how to evaluate people with disabilities and judge them. Supporters of the movement argue that children with disabilities should not be adapted to the framework, as implied by the integration model, but on the contrary - that the framework should be adapted to the children. For example, instead of providing the student with a sequence of special education framework, as suggested by the integration model, he should be given a series of services within a regular class. The services will be ranked according to the scope of the class and according to the degree of intensity of the adjustments required. ${ }^{13}$ This view stems from the movement's fierce belief that equality is a moral value that should be protected unconditionally. ${ }^{14}$

רייטר, ש' (1990 .(דרכי עבודה בחינוך מיוחד. סוגיות בחינוך מיוחד, יחידה מס' 11 ,תל אביב: 13 האוניברסיטה הפתוחה: מליבה:

רונן, ח' (2007). שילוב - סוגיות ומחלוקות ש’ רייטר ו' לייזר וג' אבישר (עורכים), שילובים: 14

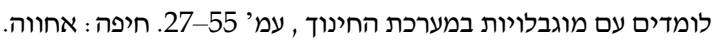




\section{Inclusion}

Inclusion is a concept from the field of psychology that describes the ability to accept feelings and difficulties of another person as they are, without rejecting or denying them, or transferring them to others in an unadapted manner. Inclusion is associated with the ability to observe difficult emotions and situations or interpret them in a way that will enable accepting and assimilating them.

Inclusive schools were first established in Israel in 2017. Those first four schools host students with special needs and "regular" students. Dozens of additional inclusive schools are about to open in 2021. This reflects the desire of the educational system in Israel to prioritize the inclusion program over the integrative program.

\section{Inclusive schools in Israel}

An inclusive school is a school built entirely around the inclusion of children with special needs alongside "ordinary" children. Adi Altschuler, a social entrepreneur and the founder of Wings of Krembo a youth movement for children with and without special needs, initiated the establishment of inclusive schools so that the inclusion and participation revolution will take place in formal education as well.

In inclusive schools, every third student has special needs. The school is physically and pedagogically adapted for this purpose. The curriculum provides educational quality on the one hand, and inclusive and integrative thinking on the other. Teachers are substantially supported by special education teachers and integration assistants. All staff members are trained according to the inclusion model.

\section{Educational inclusion}

Educational inclusion is based upon several social and educational approaches. Education is part of society and therefore must apply social norms and advocate moral values. Educational inclu- 
sion stresses the acceptance of the individual, regardless of who he or she is, by providing the setting and opportunity to express their needs and receive the optimal conditions to realize their abilities, even if they are different from those of their peers.

The principle underlying the inclusion policy is the aspiration of the education system to create meaningful learning that has involvement, belonging, interest, enthusiasm, emotional and mental connection, and constant growth for all participants. Israel is a multicultural and diverse society. Therefore, there is a need to apply concepts of inclusion and diversity in various services and settings. The Israeli educational system consists of students with different characteristics and diverse needs. Each student has strengths, as well as skills and competencies that require support and enhancement. The different educational frameworks aim to accommodate each student's needs, as part of the institution's raison d'être. ${ }^{15}$

The Ministry of Education has set inclusion as a pivotal goal in its working plans since 2012, recognizing that openness to learning about and getting acquainted with "others", will advance us to be the type of society we aspire to. An inclusive school provides its students with the optimal conditions for their development, advancement, and mental well-being. It is a place that recognizes diversity, flexibility, and creative thinking. It works to create a sense of belonging, protection, and meaning, and maintains a meaningful dialogue with all its members - students, teachers and other staff members, parents, and the surrounding community.

In recent years, school inclusion has become a priority in the national agenda. Many teachers from regular education receive special education training, and regular schools are transforming into inclusive schools. An inclusive school enables children with mild, moderate, and severe disabilities to integrate into regular settings near their homes and acquire the same education as their peers, only adapted to their individual needs. The school inclusion pro-

${ }^{15}$ R. Slee (2011). The irregular school: Exclusion, schooling and inclusive education. Oxon: Routledge. 
gram has a vital role in educating future generations to be tolerant and accepting of all others.

In the educational system in Israel, as in other countries, there are students with diverse abilities and different needs. The inclusion and participation of all students is a top priority. An inclusive society recognizes the added value of diversity and its advantages. People are different from one another - each has abilities, needs, wishes, and desires, and all individuals can contribute to shaping our society.

The commitment to the inclusion and integration of students is an important challenge for the teaching staff. This commitment means that the staff members maintain the perception that every student is entitled to study within his immediate community and to experience shared living throughout the day, in educational institutions, in after-school activities, and in extra-educational frameworks. Moreover, it should be acknowledged that different responses to different students benefit the entire class and promote it as a whole.

Inclusion in educational settings relates to four central "action areas": pedagogical inclusion, emotional-social inclusion, organizational inclusion, and environmental inclusion. This division into four areas is not dichotomous, but it allows for an in-depth, holistic observation of the educational institution as one organism with a variety of study trends, treatment options and tailored teaching.

Inclusion and participation at schools are reflected in the provision of multiple responses to a variety of needs, in those four "action areas". This series of responses allows each student to progress and realize his potential, find interest in things, expand his social skills, and enrich his emotional world.

The ability of the teaching staff to address the important moral and professional challenges they face is a key goal for the educational system. The inclusion and participation of students with special needs strengthen the ability of the teaching staff to address those important moral and professional challenges. These challenges provide an opportunity for enriching professional and emotional experiences. 


\section{Views of student teachers and teachers toward inclusion of students with special needs}

One of the factors influencing teachers' attitudes is knowledge about children with special needs and their integration in regular classes. This knowledge is acquired during both teaching training and in service. Studies confirm the assumption that training in special education, during those two professional periods, is necessary in order to reduce objections to integration. Enriching teachers' knowledge about integration and ways to meet the needs of integrated students may reduce negative attitudes toward integration. ${ }^{16}$ Teachers who reported a high level of special education training, or experience in teaching students with special needs, held more positive views toward integration. ${ }^{17}$

Rothenberg and Reiter (2002) conducted in a study in which 92 Israeli education students from non special-education study programs participated. ${ }^{18}$ The study group included 59 students who took an introductory course in special education; the control group included 33 students who did not take that course. The study addressed the question of whether there is a connection between taking introductory courses in special education and more positive attitudes towards children with special needs and their integration in regular classes. The syllabi in those courses were based on pedagogical and didactic principles, mainly education to equality, justice, and fairness towards all groups and to all individuals. The study showed that students from the study group changed their attitudes towards children with special needs and their integration in the regular educational system. The change was apparent in all components of one's views: emotional, behavioral, and cognitive.

17 K. Parasuram (2006). Variables affecting teachers' attitudes towards disability and inclusive education in Mumbai, India. Disability and Society, 21 (3), pp. 231-242.

17 D. Supriyanto (2019). Teachers' attitudes towards inclusive education: a literature review. IJDS: Indian Journal of Disability Research, 6 (1), pp. 29-37.

רוטנברג, י' ורייטר, ש'. (2002.(שינוי עמדותיהם של סטודנטים במכללה להכשרת מורים לגבי 18 ילדים בעלי צרכים מיוחדים ושילובם בכיתות שמית הרגלת לחילות. מעוף ומעשה, 2002-23 
These studies indicate a positive relationship between learning about disabilities and preparing to work with disabled students, and positive attitudes of teachers towards inclusion. Studies also indicate that positive attitudes towards inclusion lead to optimal integration. ${ }^{19}$ Therefore, in view of the $11^{\text {th }}$ amendment to the Special Education Law (1988), which advocates inclusion and participation of every student with special needs in Israel, we are committed to preparing the educational staff early on in their academic training, in order to include and integrate all special education students within regular education settings.

\section{Recommendations and a training model}

Studies indicate that the status of special education teachers, subject teachers, and educators has been undergoing change, in the trend toward inclusive educational system. Teachers do not always know what their status is, and the school organizational structure has changed. Teachers are required to work collaboratively and synthesize the information collected about each student into personalized programs aimed at advancing students with special needs. As a pedagogical instructor and a college lecturer, I meet student teachers with special education background as well as subject student teachers; I also meet teachers in whose classes there are students with special needs. From conversations I've had with them and the results of the studies detailed above, I see the need to prepare those future teachers already in their academic training, familiarizing the student teachers with the type of tasks they'll need to perform in inclusive schools. Following the inclusion goals set by the Ministry of Education and the planned follow-up goals in the State of Israel, I recommend that inclusion programs be part of the academic studies and prepare student teachers for educational inclusion and inclusive teamwork.

19 D. Supriyanto (2019). Teachers' attitudes towards inclusive education: a literature review. IJDS: Indian Journal of Disability Research, 6(1), pp. 29-37. 
Since student teachers who do not specialize in special education will be required, according to the school inclusion program, to take part in inclusion programs of students with special needs, I propose that in the first academic year all student teachers in Israel should be introduced to inclusive education, to facilitate their active participation in the schools' inclusion programs. Teaching curricula should include courses on social inclusion. Graduates of such courses will acquire tools to instill in students the values of social and emotional inclusion of students with special needs. The model is based on the fact that the field of inclusion is an integral part of the degree in education. Inclusion-related courses will encompass four semester courses in each academic year and on the fourth (practical training) year, student teachers will be required to gain practical experience in an inclusive class or school. The training model for the three academic years contains courses and workshops in the following topics:

1. Inclusive pedagogy and optimal differential learning.

2. Inclusive values and social and emotional integration.

3. Exposure to the various disabilities and their characterization.

4. Teamwork and collaboration.

5. Principles of inclusive schools and their inter-organizational working processes.

Practical experience must include differential learning and coping with social and emotional differences.

The principle of inclusion must be an integral part of the curricula at teachers' colleges and universities if we want all schools to be inclusive. It should be woven - both theoretically and practically into the academic studies, to prevent a situation whereby a teacher encounters the concept of inclusion and is trained for it only after receiving certification.

I sincerely hope that the inclusion model that is gaining momentum throughout the world and in Israel will be a part of our outlook and that the inclusion of students with special needs at an early age will contribute to community building and create an inclusive generation of people who consider everyone equal - a society with tolerance to diversity and accepting of others completely. 


\section{References}

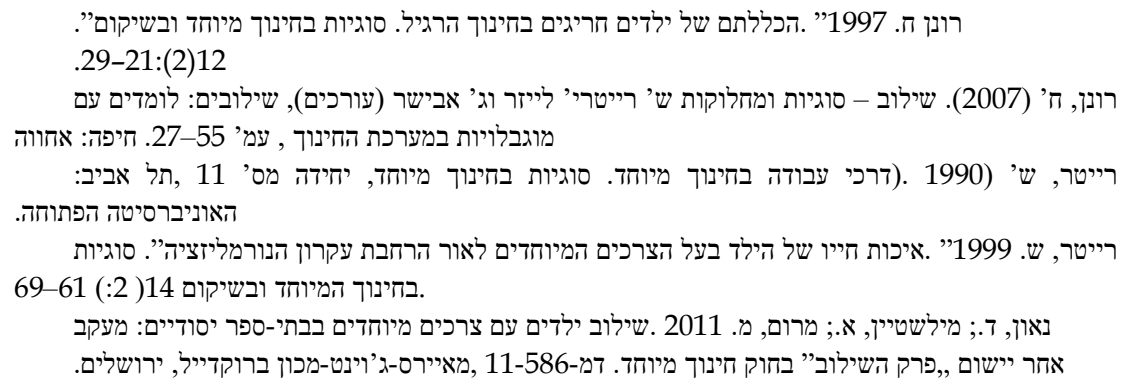

Ainscow M., Booth T. \& Dyson A. (2006). Improving schools, developing inclusion. New York, NY: Routledge.

Ainscow M., Sandill A. (2010). Developing inclusive education systems: the role of organizational cultures and leaders. International Journal of Inclusive Education, 14(14), pp. 104-111.

Aloni N. (2008). Empowering dialogues in humanistic education. Bnei Brak: Hakibbutz Hameuhad.

Anderson J., Boyle C. \& Deppeler (2014). The ecology of inclusive education, [in:] Z. Zhang, P.W.K. Chan \& Boyle C. (Eds.), Equality in Education: Fairness and Inclusion, Rotterdam, Sense, pp. 23-34.

Artiles, A.J., \& Kozleski E.B. (2007). Beyond convictions: Exploring culture, history, and power in inclusive education.

Bender W.N., Vail C.O. \& Scott K. (1995). Teachers' Attitudes toward Increased Mainstreaming: Implementing Effective Teaching for Students with Learning Disabilities. Journal of Learning Disabilities, 28(2), pp. 87-94.

Blecker N. \& Boakes N. (2010). Creating a learning environment for all children: Are teachers able and willing, International Journal of Inclusive Education, 14, pp. 435-447.

Booth T. Ainsco T. (2002). Index for Inclusion: Promoting the Learning and Integration of All Students in the School. (Translation: Anat Seidman). Center for the Study of Container Education, Mishal Publishing.

Boyle C., Topping K. \& Jindal-Snape D. (2013). Teachers' attitudes towards inclusion in high schools, Teachers and Teaching, 19, pp. 527-542.

Change F., Early D. \& Winton P., et al. (2005). Early childhood teacher preparation in special education at 2-and 4-year institutions of higher education, Journal of Early Interventions, 27, pp. 110-123.

De Boer A., Pijl S. \& Minnaert A. (2010). Regular primary teachers' attitudes towards inclusive education: A review of the literature, International Journal of Inclusive Education, 15, pp. 331-353. 
Dori J. (2013). Education heterogeneity: optimal educational models for systemic or local coping. In Naomi Mendel Levy (Ed.), Dealing with differences between students in the Israeli education system (pp. 17-16). Lecture summary at the Israeli National Academy of Sciences.

Fakih M. (2019). Teachers' Attitudes Towards Inclusion of Learners with Disabilities at American Private Early Childhood Education in Dubai: An Investigative Study (Doctoral dissertation, The British University in Dubai (BUiD)).

Florian L. \& Rouse M. (2009). The inclusive practice project in Scotland: Teacher education for inclusive education, Teaching and Teacher Education, 25(4), pp. 594-601.

Forlin C. \& Chambers D. (2011). Teacher preparation for inclusive education, AsiaPacific Journal of Teacher Education, 39, pp. 17-32.

Harkabi A., Mendel-Levy N. (eds.). Education for All - and Everyone in the Education System in Israel. Jerusalem: Israeli National Academy of Sciences.

Joint-Ashalim (not yet published). Typology of the systemic conduct of the school for individual education.

Kim J. (2010). Influence of teacher preparation programmes on preservice teachers' attitudes towards inclusion, International Journal of Inclusive Education, 15, pp. 355-377.

Lancaster J. \& Bain A. (2010). The design of pre-service inclusive education courses and their effects on self-efficacy: A comparative study, Asia-Pacific Journal of Teacher Education, 38, pp. 117-128.

Moore P. (2012). The "containment" policy: a systemic approach aimed at fulfilling the students as individuals (presentation). A learning day about the bride in theory, research, and practice.

Parasuram, K. (2006). Variables affecting teachers' attitudes towards disability and inclusive education in Mumbai, India. Disability and Society, 21 (3), pp. 231-242.

Pugach M.C., \& Blanton L.P. (2012). Enacting diversity in dual certification programs, Journal of Teacher Education, 63(4), pp. 254-267

Pugach M.C., et al. (2011). A historical perspective on the role of collaboration in teacher education reform: Making good on the promise of teaching all students, Teacher Education and Special Education, 34(3), pp. 183-200.

Schalock R.L. (2000), Three Decades of Quality of life. In Wehmeyer M., Patton J. (Edt), Mental Retardation in the 21st Century, pp. 335-356. PRO-ED, Inc.

Schalock R.L. (2004). The concept of quality of life: what we know and do not know. Journal of Intellectual Disability Research, Vol. 48(3) pp. 203-216

Sharma U., Forlin C. \& Loreman T. (2008). Impact of training on pre-service teachers' attitudes and concerns about inclusive education and sentiments about persons with disabilities, Disability \& Society, 23, pp. 773-785.

Slee R. (2011). The irregular school: Exclusion, schooling and inclusive education, Oxon: Routledge. 
Supriyanto D. (2019). Teachers' attitudes towards inclusive education: a literature review. IJDS: Indian Journal of Disability Resea rch, 6(1), pp. 29-37.

UNESCO (2005). Guidelines for inclusion: Ensuring access education for all. France: UNICEF. http:/ / unesdoc.unesco.org/images/0014/001402/140224e.pdf. 